\title{
Oceanography
}

CITATION

Morris, J.T., K. Sundberg, and C.S. Hopkinson. 2013. Salt marsh primary production and its responses to relative sea level and nutrients in estuaries at Plum Island, Massachusetts, and North Inlet, South Carolina, USA. Oceanography 26(3):78-84, http://dx.doi.org/10.5670/ oceanog.2013.48.

$\mathrm{DOI}$

http://dx.doi.org/10.5670/oceanog.2013.48

COPYRIGHT

This article has been published in Oceanography, Volume 26, Number 3, a quarterly journal of The Oceanography Society. Copyright 2013 by The Oceanography Society. All rights reserved.

USAGE

Permission is granted to copy this article for use in teaching and research. Republication, systematic reproduction, or collective redistribution of any portion of this article by photocopy machine, reposting, or other means is permitted only with the approval of The Oceanography Society. Send all correspondence to: info@tos.org or The Oceanography Society, PO Box 1931, Rockville, MD 20849-1931, USA. 


\section{Salt Marsh Primary Production and Its Responses to Relative Sea Level and Nutrients in Estuaries at Plum Island, Massachusetts, and North Inlet, South Carolina, USA \\ BY JAMES T. MORRIS,}

KAREN SUNDBERG, AND

CHARLES S. HOPKINSON
ABSTRACT. Feedbacks between flooding and plant growth that help to stabilize marshes against rising sea level are being investigated in estuaries at Plum Island, Massachusetts, and North Inlet, South Carolina. Net annual primary production of the marsh grass Spartina alterniflora has been quite variable through the years, and correlates positively with sea level during the growing season at both sites. The elevation of the marsh surface relative to mean high water determines the duration of flooding, or hydroperiod, that in turn affects plant growth. The effect of flooding was tested experimentally using an in situ bioassay to simulate growth at different relative elevations. At North Inlet, we found a parabolic response to relative elevation, with clear evidence of minimum and maximum vertical limits and an optimal elevation for growth. The Plum Island bioassay provided evidence of the super-optimal side of the growth curve. In both marshes, the responses of S. alterniflora to rising sea level, at their current elevations, are consistent with the bioassay results. This growth curve is important because it defines suboptimal elevations that are unstable for marshes and super-optimal elevations that are stable. Instability results when an increase in sea level decreases primary production, leading to declines in mineral sedimentation and sediment organic matter accretion. Conversely, stability results when rising sea level stimulates primary production, leading to increased sedimentation and organic matter accretion. There also has been interannual variability in the maximum standing biomass (a proxy for productivity) of another marsh grass, Spartina patens, but no significant correlation has been found with sea level, possibly due to methodological limitations. Finally, both Spartina species responded positively to nitrogen and have remained highly productive for 13 years of fertilization at Plum Island and 30 years at North Inlet.

\section{INTRODUCTION}

Salt marshes are at risk of being overwhelmed by rising sea level. If they decline, we risk losing a wealth of ecosystem services they provide, including soil and sediment maintenance (shoreline stabilization), nutrient and water-quality regulation, food provisioning, nursery habitat for commercially important species, recreational opportunities, and hazard moderation (Barbier et al., 2011; Shepard et al., 2011). Centuries ago, New England's colonists used salt marshes as an important source of food for livestock (Sebold, 1998). Indeed, patterns of settlement proceeded up and down the coast from town and port centers, such as Boston, in proportion to the distribution of salt marshes. They were so important that land grants to settlers typically included salt marsh areas.

Salt marshes developed during times of low sea level rise (Redfield, 1972). Sea level rise is currently accelerating (Kemp 


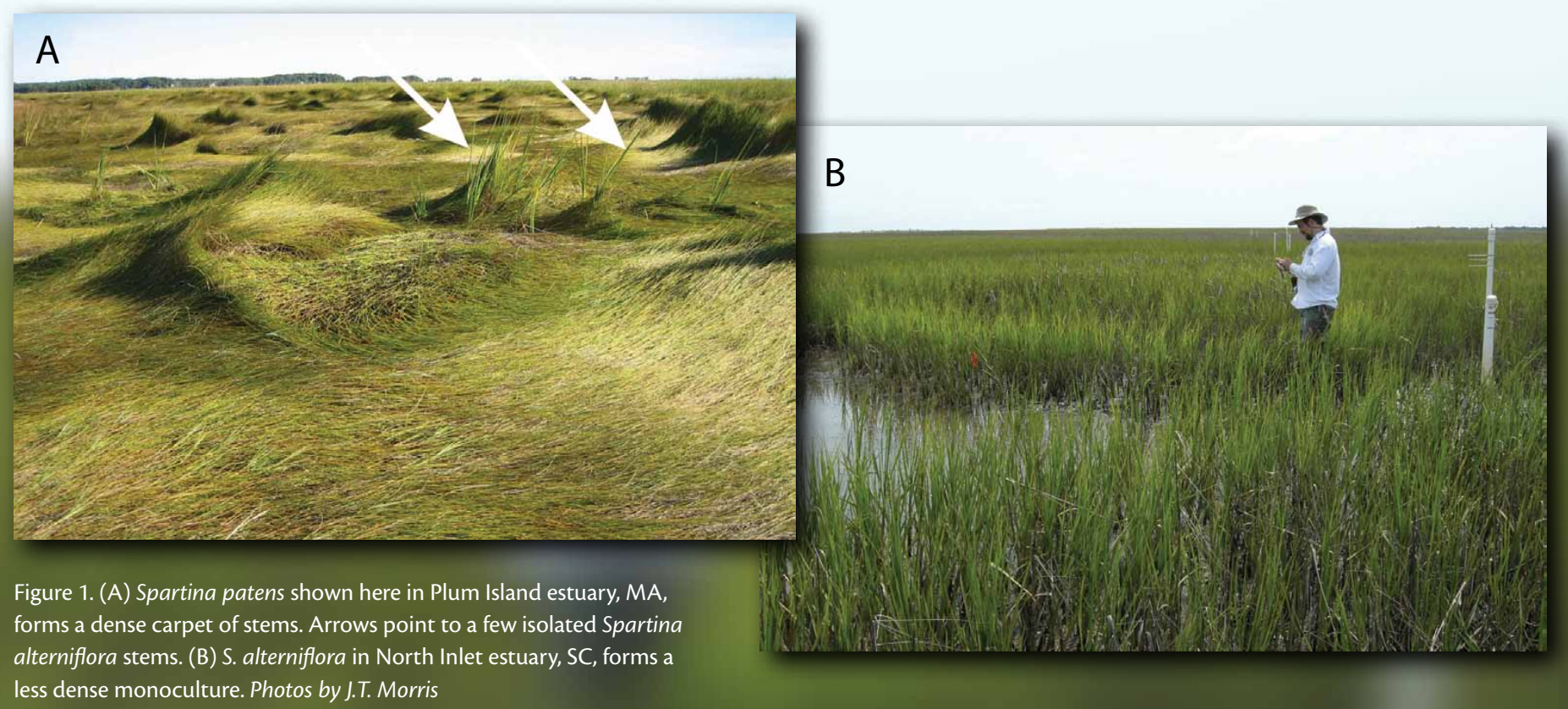

et al., 2009) and is expected to reach levels (Rahmstorf et al., 2012) that threaten to submerge coastal wetlands by the end of the century (Kirwan et al., 2010). Wetland losses could also accelerate as a consequence of erosion (Fagherazzi et al., 2013, in this issue) and coastal eutrophication (Deegan et al., 2012). Ultimately, the sustainability of these ecosystems is dependent on their ability to maintain elevation relative to sea level within a suitable vertical tidal range that lies approximately between mean high water (MHW) and mean sea level (MSL) (McKee and Patrick, 1988). Scientists at the Plum Island Ecosystem Long Term Ecological Research (LTER) site in northeastern Massachusetts have been conducting research to better understand processes that control the productivity and the capacity of tidal marshes to maintain elevation and, hence, survive despite accelerating rates of sea level rise associated with climate change. These processes are being studied at Plum Island, Massachusetts, in the cold-water Acadian biogeographic province and at North Inlet, South Carolina, in the warm-water Carolinian province.

In addition to climate, major differences between the two sites include tides, soil, and vegetation. Tide range averages $2.67 \mathrm{~m}$ at Plum Island and $1.43 \mathrm{~m}$ at North Inlet. Plum Island marshes are built on a low-grade peat, while North Inlet marshes rest on mineral sediment. Both marshes are dominated by a species of cordgrass: Spartina patens (saltmeadow cordgrass) at Plum Island (Figure 1A) and Spartina alterniflora (salt marsh smooth cordgrass) at North Inlet (Figure 1B). At Plum Island, S. alterniflora is confined largely to lower relative elevations (mean $0.9 \pm 0.3 \mathrm{~m}$ above MSL $\pm 1 \mathrm{SD}$ ), principally as a monoculture around the margins of the tidal creeks, while S. patens is found at higher elevations. The dominance of
S. patens at Plum Island can be inferred from the frequency distribution of marsh elevations (Figure 2). The modal elevation here $(1.3$ to $1.4 \mathrm{~m})$ is within the domain of $S$. patens, $1.3 \pm 0.1 \mathrm{~m}$ above MSL. At North Inlet, S. patens is rare and is typically restricted to the swales between sand dunes.

Studies begun in 1984 at North Inlet document that interannual anomalies in MSL on the order of 5 to $10 \mathrm{~cm}$ positively affect the productivity of S. alterniflora (Morris and Haskin, 1990; Morris, 2000). The effect on plant growth is thought to be due to variations in the duration (hydroperiod) and frequency of tidal flooding, which are determined largely by the marsh elevation relative to MHW. Primary production in the upper quadrant of the tidal frame (roughly the highest $25 \%$ of the intertidal zone) is greater in years of high sea level. This is key to the survival of marshes, because they trap more sediment and generate 
a greater biovolume (Blum and Davey, 2013, in this issue) when greater flooding enhances vegetation growth (Morris et al., 2002). We hypothesize that the importance of S. alterniflora at Plum Island, and probably in New England salt marshes in general, will increase at the expense of $S$. patens as sea level rise accelerates and marshes fall behind.

\section{BIOMASS AND PRODUCTIVITY}

At Plum Island, as we have seen at

North Inlet (Morris and Haskin, 1990;

Morris, 2000), net annual primary production of $S$. alterniflora has been quite variable through the years. In control plots at Plum Island where there is a continuous record since 1999, production has been as low as 343 and as high as $1,324 \mathrm{~g} \mathrm{~m}^{-2} \mathrm{yr}^{-1}$ (Figure 3B). There also is a significant correlation between aboveground net primary production and MHW at Plum Island $\left(\mathrm{r}^{2}=0.43\right.$, $\mathrm{p}=0.01$; Figure 4 ). The similarity with North Inlet interior marsh sites where production has varied from 376 to $1,479 \mathrm{~g} \mathrm{~m}^{-2} \mathrm{yr}^{-1}$ is remarkable considering the differences in the lengths of the two marshes' growing seasons. Plum Island marshes support this range of productivity even though they are restricted by a short growing season that lasts only from May through August. Within three months, starting from a barren landscape in May, stands of S. alterniflora emerge and amass an average live biomass of $543 \mathrm{~g} \mathrm{~m}^{-2}$ (Figure 5).

In contrast, the growing season at North Inlet is essentially year-round. However, differences emerge when examining different habitats within the salt marsh; at North Inlet, average S. alterniflora production in low-lying areas along creek banks $\left(1,499 \pm 642 \mathrm{~g} \mathrm{~m}^{-2} \mathrm{yr}^{-1}\right)$ is nearly twice that of higher, interior sites $\left(839 \pm 347 \mathrm{~g} \mathrm{~m}^{-2} \mathrm{yr}^{-1}, \pm 1 \mathrm{SD}\right)$.
It is important to point out that the same method has been used to estimate S. alterniflora biomass and productivity at both Plum Island and North Inlet. The method requires making monthly measurements of the heights of individual stems on permanent plots. In this way, individual stems are tracked chronologically. Transfer functions are then applied to derive time series of biomass of individual stems and their growth rates, which are summed to estimate net aboveground primary production (Morris and Haskin, 1990; Morris, 2007). Application of this method of accounting for growth was impractical for $S$. patens because of its high stem density and mat-forming growth habit (Figure 1A). Instead, measurements of maximum standing biomass derived from repeated destructive harvests of small plots of $S$. patens are used as a proxy for productivity.

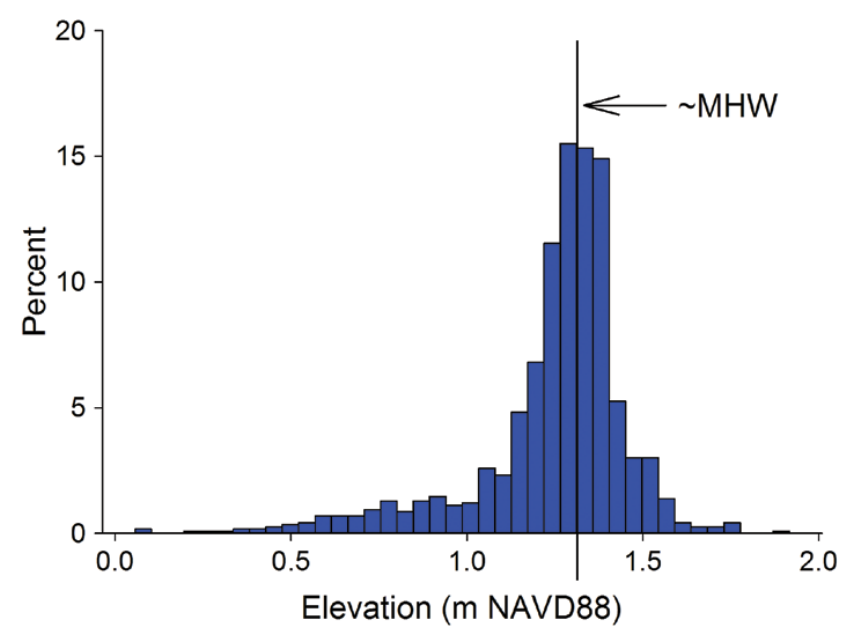

Figure 2 (above). Frequency distributions of elevations in vegetated Plum Island salt marshes, $n=1,161$ GPS points, from surveys made in 2001 and 2002.

Figure 3 (right). Plum Island (A) annual maximum aboveground biomass (mean live plus standing dead $\pm 1 \mathrm{SE}$ ) of Spartina patens in control plots and plots fertilized with nitrogen and phosphorus, and (B) mean $( \pm 1 \mathrm{SE})$ annual aboveground net primary production of S. alterniflora. Note that production of fertilized plots in B was not measured from 2004 through 2011.
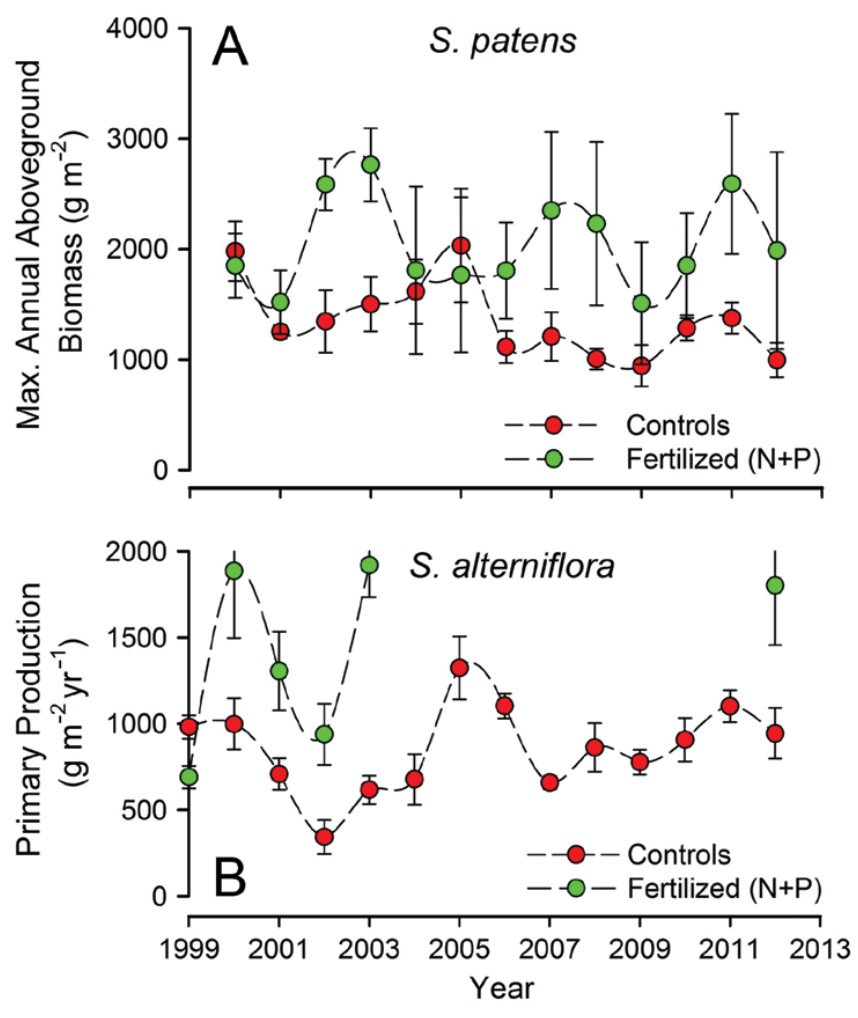
As we have seen with S. alterniflora, there has been variability in the maximum standing biomass of $S$. patens at Plum Island (Figure 3A), but no significant correlation has been found with sea level. This may be due to the low signal-to-noise ratio of the harvest method. In contrast to the census of fixed populations of $S$. alterniflora, the harvest method (Smalley, 1958; Wiegert and Evans, 1964) is subject to random errors of spatial variation in biomass density (Singh et al., 1984). Measuring primary production by harvesting plots of plants is akin to estimating growth rates of individuals in a population by repeatedly weighing a different random sample of individuals drawn from that population and summing the repeated differences in their mean weights. The sampling error of the $S$. patens biomass in the control treatment averaged $15 \%$ (standard error), and the lack of a significant correlation with sea level therefore is not surprising.

The high standing biomass at Plum Island of $S$. patens, averaging $1,257 \mathrm{~g} \mathrm{~m}^{-2}$, relative to $547 \mathrm{~g} \mathrm{~m}^{-2}$ for S. alterniflora, is not unusual, although the casual observer could conclude otherwise. $S$. patens is a wispy marsh phanerogam (a plant that produces seed), with stem densities that approach $4,000 \mathrm{~m}^{-2}$. Its stems often lie prostrate, forming a dense, green carpet (Figure 1A) that, owing to the horizontal orientation of the leaves, maximizes the interception and harvesting of solar energy. Studies conducted in Louisiana marshes where plant growth occurs year-round have shown that aboveground primary productivity of $S$. patens is 1.6 to 3 times higher than that of the more robust $S$. alterniflora (Hopkinson et al., 1978, 1980).

\section{NUTRIENT EFFECTS}

As mentioned earlier, losses of salt marsh habitat could accelerate as a consequence of eutrophication (Deegan et al., 2012). Conflicting results from other studies in which nutrients have been added experimentally (e.g., Anisfeld and Hill, 2011) motivated an analysis of the effects of nutrients on biomass and primary production. Experimental plots started at Plum Island in 1999 have been treated with nitrogen and phosphorus fertilizer, added approximately monthly from April through September, initially at rates of $15 \mathrm{~mol} \mathrm{~N} \mathrm{~m}^{-2} \mathrm{yr}^{-1}$ and $7.5 \mathrm{~mol} \mathrm{P} \mathrm{m}^{-2} \mathrm{yr}^{-1}$, and since 2002 at rates of $7.5 \mathrm{~mol} \mathrm{~N} \mathrm{~m}^{-2} \mathrm{yr}^{-1}$ and $3.75 \mathrm{~mol} \mathrm{P} \mathrm{m}^{-2} \mathrm{yr}^{-1}$.

Both Spartina species responded positively to fertilization after one year (Figure 3). In plots of S. alterniflora treated with both nitrogen and phosphorus, biomass increased nearly $50 \%$ (Figure 5). The biomass on fertilized plots of $S$. patens increased $62 \%$ when

James T. Morris (morris@biol.sc.edu) is Professor and Director, Belle Baruch Institute for Marine \& Coastal Sciences, University of South Carolina, Columbia, SC, USA. Karen Sundberg is Research Specialist, Baruch Marine Field Laboratory, University of South Carolina, Georgetown, SC, USA. Charles S. Hopkinson is Professor, Department of Marine Sciences, University of Georgia, Athens, GA, USA.

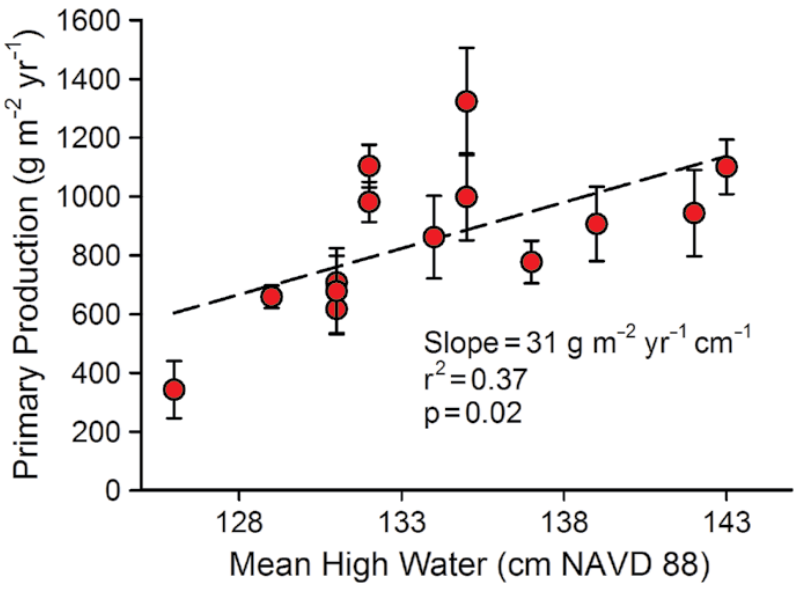

Figure 4. Net aboveground primary production (mean $\pm 1 \mathrm{SE}$ ) of S. alterniflora at Plum Island as a function of mean high water level (MHW). Plum Island data are annual values, averaged over all control plots, all of which are at approximately the same relative elevation (112 cm NAVD88).

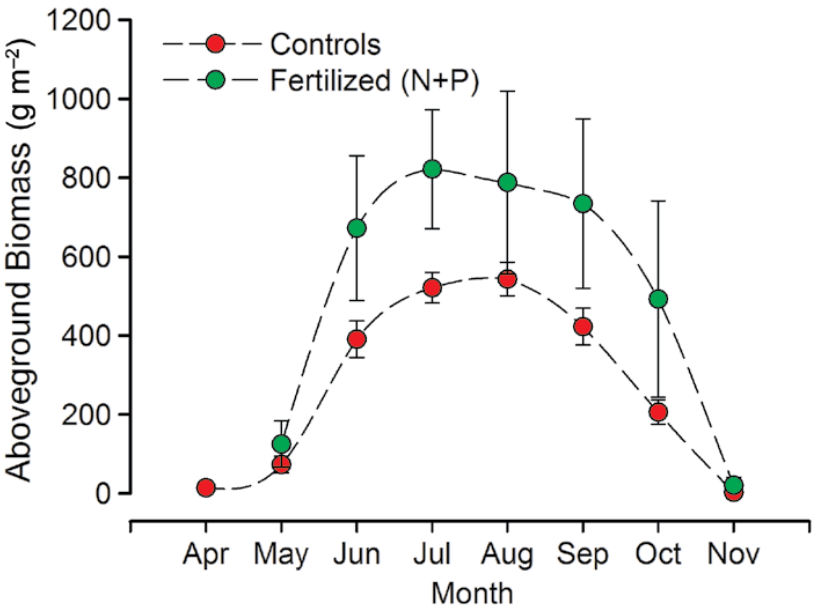

Figure 5. Monthly mean $( \pm 1 \mathrm{SE})$ aboveground biomass of S. alterniflora at Plum Island. 
treated with nitrogen and phosphorus

(Figure $3 \mathrm{~A}$ ), and $45 \%$ and $31 \%$ when treated solely with nitrogen or phosphorus, respectively. Production of S. alterniflora at Plum Island was stimulated by the same amount in plots treated only with nitrogen and with both nitrogen and phosphorus, but plots treated only with phosphorus did not respond. The enhanced production in the fertilized plots shows no indication of increasing further or declining, even after 13 years of fertilization. This is an important clue, but in the absence of clear evidence about effects on sediment organic matter and soil strength, it does not resolve the question about the effect of coastal eutrophication on marsh sustainability.

Plant growth at North Inlet is also limited by nitrogen with evidence of colimitation by phosphorus (Sundareshwar et al., 2003). In the interior marsh, S. alterniflora aboveground production averaged 3,630 $\pm 2,188 \mathrm{~g} \mathrm{~m}^{-2} \mathrm{yr}^{-1}$ in plots treated with both nitrogen and phosphorus and was 4.3 times greater than in controls. In contrast, fertilization increased production of S. alterniflora at Plum Island only by 1.7 times. Growth is exponential, and such high production in fertilized sites at North Inlet may be a consequence of its year-round growing season.

\section{MEAN HIGH WATER LEVEL}

The overall rate of increase in MHW in the Northeast since 1984, $0.4 \mathrm{~cm} \mathrm{yr}^{-1}$ (Figure 6), is significantly higher than the trend during the last century. The current rate may be inflated by sampling a low-frequency cycle, such as the 18.6 year lunar nodal cycle (Baart et al., 2012), although trend analysis of station data exceeding 75 years confirms an acceleration in sea level rise (Boon,
2012). The magnitudes of current and past trends are greatly exceeded by interannual variability (Figure 6). MHW averaged over the growing season (May through August from 1984 through 2012) has been as low as $126 \mathrm{~cm}$ and as high as $143 \mathrm{~cm}$. The maximum annual change in MHW over this period was $+6 \mathrm{~cm}$, and there have been sequences of high and low years such as the $14 \mathrm{~cm}$ increase that occurred between 2007 and 2011. The responses of the marsh to these events should be more visible than its responses to long-term trends.

\section{THE RESPONSE OF GROWTH TO RELATIVE ELEVATION}

The duration of flooding (i.e., marsh hydroperiod) is a critically important variable for coastal wetland plants. It is determined by the relative elevation of the marsh within the intertidal zone. For marsh elevations between MHW and MSL, depth below MHW is a good proxy for hydroperiod and accounts for changes in both mean sea level and tidal amplitude. The sensitivity of vegetation to changes in sea level varies as a function of elevation within the intertidal zone, and should be greatest near the upper and lower vertical limits of growth. In the middle of the range, growth should be greatest and least sensitive to sea level change. At elevations less than optimal, growth of vegetation should respond negatively, while at elevations greater than optimal, growth should respond positively to an increase in flooding and sea level. Plum Island marshes are closer to the local MHW level, a super-optimal elevation for growth, than are most North Inlet marshes.

The effect of hydroperiod was tested using planters consisting of PVC pipe, termed "marsh organs," placed in the marsh at Plum Island (Figure 7) and North Inlet to simulate growth of vegetation at different relative elevations. Pipes were filled with sediment taken from the adjacent mudflat and planted in the spring with S. alterniflora plugs taken from the marsh. All of the pipes had open bottoms resting on tidal mudflat, and their lengths differed by approximately $15 \mathrm{~cm}$ between rows (six pipes per row). The gradient in plant growth at different elevations is clear. The weights of harvested plants varied with relative elevation in both estuaries (Figure 8). Growth responses in these bioassays are consistent with those of in situ net primary production to anomalies in $\mathrm{MHW}$ (e.g., Figure 4), and they conclusively

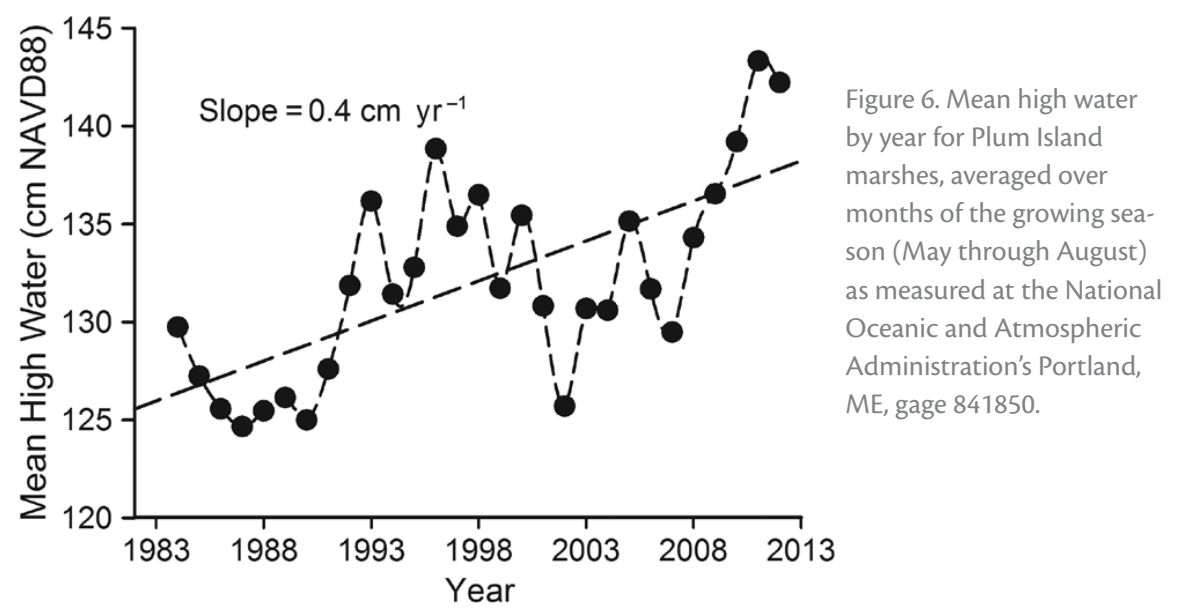


demonstrate the feedback between growth and relative elevation. This important feedback helps to explain how marshes track rising sea level.

The North Inlet growth response shows upper and lower limits and a midrange optimum (Figure 8). A parabola fits these data nicely. It is a good example of Shelford's Law of Tolerance (Shelford, 1931), which states that the success of an organism is determined by a complex set of conditions, and that each individual or population has minimum, maximum, and optimum factors that determine its success. With respect to S. alterniflora, at the high end, osmotic stress from hypersalinity or drought most likely limits growth, while the lower limit is probably a function of hypoxia. The direction of the response will depend on the relative elevation, which can be either superoptimal or suboptimal. At suboptimal elevations, the response of growth to a rise in sea level should be negative and destabilizing, except in situations of marsh progradation where high sedimentation rates build marshes. The suboptimal side of the curve is destabilizing because an increase in sea level will decrease primary production, leading to a decline in sediment organic matter accumulation and accretion of mineral sediment.

Hydroperiod is only a proxy for other variables that affect salt marsh primary production such as soil salinity, nitrogen availability, and hypoxia (Mendelssohn and Morris, 2000). Moreover, neither hydroperiod nor its companion relative elevation is the only determinant of soil salinity or hypoxia. They are also determined by soil permeability, bioturbation, drainage, precipitation, and evapotranspiration, in addition to flood duration and frequency. Plants growing on a creek bank riddled with crab burrows are unlikely to have precisely the same response to a change in sea level that plants growing high on an expansive, poorly drained, flat marsh platform would. Likewise, the response of a single species or of different species in a brackish marsh should differ from the response in a hypersaline marsh. Consequently, the response of vegetation to sea level across a mosaic of marsh landscapes could vary. The single growth response curve proposed by Morris et al. (2002) and shown for North Inlet in Figure 8 is really a slice through an $\mathrm{n}$-dimensional hyperspace (sensu Hutchinson, 1957). It is one of a family of curves, each representing a different combination of variables, such as salinity and sediment permeability.

\section{CONCLUSIONS}

- Research conducted in South Carolina and Massachusetts salt marshes is being done to develop a predictive understanding of the response of the dominant marsh vegetation, S. alterniflora and S. patens, respectively, to sea level rise and nutrients.

- Field observations of plant growth and relative mean sea level along with bioassays in which marsh elevation was varied experimentally show that

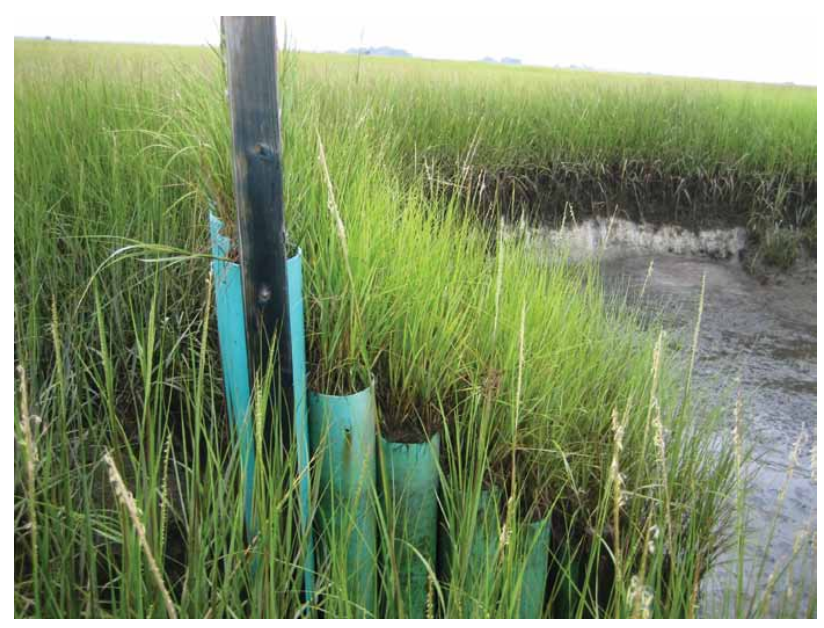

Figure 7. Profile view of a "marsh organ" planted with S. alterniflora at the edge of a Plum Island salt marsh. Photo by J.T. Morris, 2008

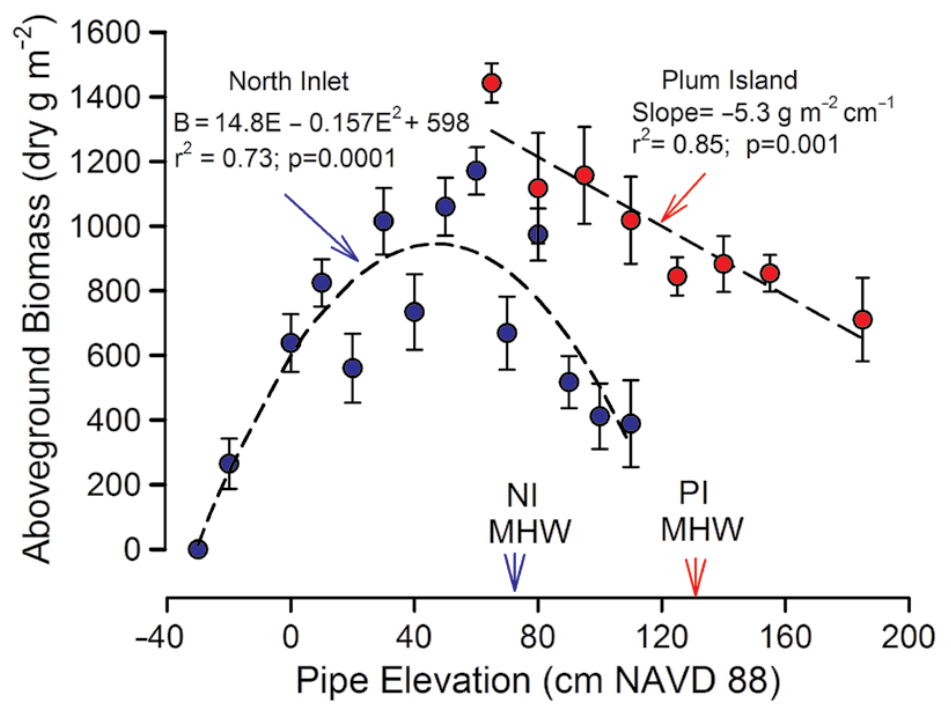

Figure 8. End-of-season (2008) total aboveground standing biomass (mean $\pm 1 \mathrm{SE}$ ) of S. alterniflora from marsh organs at Plum Island (red circles) (see Figure 7) and North Inlet (blue circles) as a function of relative elevation. Plum Island data were collected in 2008, North Inlet data are means of collections made during 2005-2010. The mean high water (MHW) levels at North Inlet $(\mathrm{NI})$ and Plum Island $(\mathrm{PI})$ are indicated. 
productivity of S. alterniflora in the upper quadrant of the tidal frame responds positively to an increase in mean high water level.

- Observations also show that the addition of nitrogen enhances productivity of S. alterniflora and S. patens, and that high productivity has been maintained for 13 years of fertilization at Plum Island and 30 years at North Inlet.

- We posit that the productivity of S. alterniflora at Plum Island will increase initially as sea level rises, but ultimately will decline once a threshold flooding depth or duration is exceeded. We expect that the high elevation $S$. patens marshes typical of many New England marshes are especially vulnerable to accelerating sea level rise and that their areal expanse will decrease in favor of S. alterniflora.

\section{ACKNOWLEDGEMENTS}

Research was supported by grants

from the National Science Foundation's LTER and LTREB programs. We thank two anonymous reviewers and Karen McGlathery who provided constructive criticisms. We gratefully acknowledge the field GPS survey assistance of Josh Goldstein and Corey Lawrence, research assistants with the Plum Island

\section{Ecosystems LTER. 巴ه]}

\section{REFERENCES}

Anisfeld, S.C., and T.D. Hill. 2011. Fertilization effects on elevation change and belowground carbon balance in a Long Island Sound tidal marsh. Estuaries and Coasts 35:201-211, http:// dx.doi.org/10.1007/s12237-011-9440-4.

Baart, F., P.H.A.J. van Gelder, J. de Ronde, M. van Koningsveld, and B. Wouters. 2012. The effect of the 18.6-year lunar nodal cycle on regional sea-level rise estimates. Journal of Coastal Research 28:511-516, http://dx.doi.org/10.2112/ JCOASTRES-D-11-00169.1.
Barbier, E.B., S.D. Hacker, C. Kennedy, E.W. Koch, A.C. Stier, and B.R. Silliman. 2011. The value of estuarine and coastal ecosystem services. Ecological Monographs 81:169-193, http:// dx.doi.org/10.1890/10-1510.1.

Blum, L.K., and E. Davey. 2013. Below the salt marsh surface: Visualization of plant roots by computer-aided tomography. Oceanography 26(3):85-87, http://dx.doi.org/ 10.5670/oceanog.2013.49.

Boon, J.D. 2012. Evidence of sea level acceleration at US and Canadian tide stations, Atlantic Coast, North America. Journal of Coastal Research 28:1,437-1,445, http://dx.doi.org/ 10.2112/JCOASTRES-D-12-00102.1.

Deegan, L.A., D.S. Johnson, R.S. Warren, B.J. Peterson, J.W. Fleeger, S. Fagherazzi, and W.M. Wollheim. 2012. Coastal eutrophication as a driver of salt marsh loss. Nature 490:388-392, http://dx.doi.org/10.1038/ nature11533.

Fagherazzi, S., G. Mariotti, P.L. Wiberg, and K.J. McGlathery. 2013. Marsh collapse does not require sea level rise. Oceanography 26(3):70-77, http:// dx.doi.org/10.5670/oceanog.2013.47.

Hopkinson, C.S., J.G. Gosselink, and R.T. Parrondo. 1978. Aboveground production of seven marsh plant species in coastal Louisiana. Ecology 59:760-769, http:// dx.doi.org/10.2307/1938780.

Hopkinson, C.S., J.G. Gosselink, and R.T. Parrondo. 1980. Production of coastal Louisiana marsh plants calculated from phenometric techniques. Ecology 61:1,091-1,098, http://dx.doi.org/ $10.2307 / 1936828$.

Hutchinson, G.E. 1957. Concluding remarks. Cold Spring Harbor Symposium on Quantitative Biology 22:415-442.

Kemp, A.C., B.P. Horton, S.J. Culver, D.R. Corbett, O. van de Plassche, W.R. Gehrels, B.C. Douglas, and A.C. Parnell. 2009. Timing and magnitude of recent accelerated sealevel rise (North Carolina, United States). Geology 37:1,035-1,038, http://dx.doi.org/ 10.1130/G30352A.1.

Kirwan, M.L., G.R. Guntenspergen, A. D’Alpaos, J.T. Morris, S.M. Mudd, and S. Temmerman. 2010. Limits on the adaptability of coastal marshes to rising sea level. Geophysical Research Letters 37, L23401, http://dx.doi.org/ 10.1029/2010GL045489.

McKee, K.L., and W.L. Patrick. 1988. The relationship of smooth cordgrass (Spartina alterniflora) to tidal datums: A review. Estuaries 11:143-151, http://dx.doi.org/10.2307/1351966.

Mendelssohn, I.A., and J.T. Morris. 2000. Ecophysiological controls on the growth of Spartina alterniflora. Pp. 59-80 in Concepts and Controversies in Tidal Marsh Ecology. N.P. Weinstein and D.A. Kreeger, eds, Kluwer Academic Publishers.
Morris, J.T. 2000. Effects of sea level anomalies on estuarine processes. Pp. 107-127 in Estuarine Science: A Synthetic Approach to Research and Practice. J. Hobbie, ed., Island Press.

Morris, J.T. 2007. Estimating net primary production of salt-marsh macrophytes. Pp. 106-119 in Principles and Standards for Measuring Primary Production. T.J. Fahey and A.K. Knapp, eds, Oxford University.

Morris, J.T., and B. Haskin. 1990. A 5-yr record of aerial primary production and stand characteristics of Spartina alterniflora. Ecology 71:2,209-2,217, http://dx.doi.org/ 10.2307/1938633.

Morris, J.T., P.V. Sundareshwar, C.T. Nietch, B. Kjerfve, and D.R. Cahoon. 2002. Responses of coastal wetlands to rising sea level. Ecology 83:2,869-2,877, http://dx.doi.org/ 10.1890/0012-9658(2002)083[2869:ROCWTR] 2.0.CO;2.

Rahmstorf, S., G. Foster, and A. Cazenave. 2012. Comparing climate projections to observations up to 2011. Environmental Research Letters 7, 044035, http://dx.doi.org/ 10.1088/1748-9326/7/4/044035.

Redfield, A.C. 1972. Development of a New England salt marsh. Ecological Monographs 42:201-237, http:// dx.doi.org/10.2307/1942263.

Sebold, K.R. 1998. The low green prairies of the sea: Economic usage and cultural construction of the Gulf of Maine salt marshes. Doctoral dissertation, University of Maine, 315 pp.

Shelford, V.E. 1931. Some concepts of bioecology. Ecology 12:455-467, http://dx.doi.org/ 10.2307/1928991.

Shepard, C.C., C.M. Crain, and M.W. Beck. 2011. The protective role of coastal marshes: A systematic review and meta-analysis. PLoS ONE 6:e27374, http://dx.doi.org/10.1371/ journal.pone.0027374.

Singh, J.S., W.K. Lauenroth, H.W. Hunt, and D.M. Swift. 1984. Bias and random errors in estimators of net root production: A simulation approach. Ecology 65:1,760-1,764, http:// dx.doi.org/10.2307/1937771.

Smalley, A.E. 1958. The role of two invertebrate populations, Littorina irrorata and Orchelium fidicinium, in the energy flow of a salt marsh ecosystem. Doctoral dissertation, University of Georgia, Athens, GA, USA.

Sundareshwar, P.V., J.T. Morris, E.K. Koepfler, and B. Fornwalt. 2003. Phosphorus limitation of coastal ecosystem processes. Science 299:563-565, http://dx.doi.org/10.1126/ science. 1079100.

Wiegert, R.G., and F.C. Evans. 1964. Primary production and the disappearance of dead vegetation on an old field in southeastern Michigan. Ecology 45:49-63, http://dx.doi.org/ $10.2307 / 1937106$. 